\title{
Development of the Institutional and Economic Mechanism for Managing the Regional Real Estate Market
}

\author{
Tagir Hametov ${ }^{1}$ and Irina Ishamyatova \\ Penza state university of architecture and construction, Faculty of Territory Management, Penza, \\ Russia
}

\begin{abstract}
A detailed analysis of the concepts of "economic" and "institutional" mechanism characterizing the current stage of economic development has been conducted. The socio-economic development of the residential real estate market at the level of the Russian Federation and the Penza Region, which is a developing region, has been studied. Based on the analysis of the main economic indicators of the residential real estate market, positive and negative aspects have been revealed. A model of the institutional and economic mechanism for managing the regional real estate market has been developed. The model reveals the essence of the effectiveness of the institutional and economic mechanism showing the dependence of the effectiveness of the institutional mechanism on the behavior of the main economic agents. A set of organizational, legal and economic measures, the implementation of which on a practical level contributes to the development of the residential real estate market, has been proposed.
\end{abstract}

\section{Introduction}

The modern real estate market is in the development stage and acts as a complex mechanism ensuring the interaction of economic agents through a restriction system and support programs. The purpose of this work is to develop a model of the institutional and economic mechanism for managing the regional real estate market in a transforming economy.

The scientific-theoretical and methodological significance of the work lies in the fact that the main proposed provisions for the establishment and improvement of the institutional and economic mechanism can be applied as indicators characterizing the current stage of development of the real estate economy, as well as in conducting the educational process in disciplines: economic theory, macroeconomics, institutional economy. The practical significance of the research is the possibility of using the results in developing programs to improve the functioning of the real estate market.

\footnotetext{
${ }^{1}$ Corresponding author: hametovt@mail.ru
} 


\section{Material and methods}

We will analyze the scientific and educational economic literature in order to trace the formation and improvement of the definition of the institutional and economic mechanism.

For the first time, the concept of "economic mechanism" was used by classics of economic theory. K. Marx explained this concept in more details through the concepts of "basis" and "superstructure" [1]. F. Quesnay distinguished the market mechanism, and the transition to farming considered as the basis of this mechanism [2]. A. Smith described the whole mechanism of economic activity based on the concept of "economic man" and "invisible hand of the market", which, in his opinion, were "inevitable economic laws" [3]. W. Eucken noted that any society was subject to two forms of economic order: centrally controlled and competitive [4].

The modern theory of economic mechanism was formed thanks to L. Hurwicz, E. Maskin and R. Myerson. According to L. Hurwicz, the economic mechanism is a communication system, where participants exchange messages with each other and with the center, which allows forming an economic result. [5].

The term "institutional mechanism" was first mentioned by K. Polanyi, who linked the effective work of the institutional mechanism with State intervention in economic processes and commodity exchange [6]. J. Commons believed that the institutional mechanism should realize the expectations through the process of determining value, taking into account transaction costs. [7]. J.K. Galbraith analyzes the influence of the institutional mechanism on the behavior of people through the influence of the technostructure, and the characteristics of individuals arising from the influence of the institutional mechanism are functions of the institutional environment [8]. According to North, the institutional mechanism is more important than the economic mechanism, since it is precisely the set of institutions that determine the behavior of individuals regulating the interrelations of the exchange, and, accordingly, they determine the functioning mechanism for the politicaleconomical system [9]. K. Arrow determined the institutional mechanism as a resource allocation mechanism, L. Thévenot - as the coordination of actions, C. Ménard - as an association of partners for the enterprise establishment [10].

Among domestic economy scholars referring to this term, we should note N.N. Lebedev, I.S. Averin, V.R. Salyev, S.O. Iashchenko, M.E. Nikifirov, I.S. Averin, S.V. Istomin, Ia. Kronrod, and O.N. Inshakov [10, 11].

Thus, we have considered the formation of the concepts of "institutional" and "economic" mechanism that characterize the current stage of economic development. It should be noted that representatives of foreign economic thought and Russian economists do not give definitions that reveal the content of the institutional mechanism and its effectiveness adequate to the current stage of economic development.

Economic entities of the real estate market are: sellers (lessors); buyers (lessees); real estate institutions - entities representing the interests of the State and acting on its behalf; real estate non-institutions are entities operating on a commercial basis [12].

We will analyze the macroeconomic situation of the residential real estate market in the Russian Federation and in a specific region - the Penza Region. The statistics showed that in the Penza Region 887 thousand sq. m. of apartment buildings were put into operation in 2017 and 624.8 thousand sq. m. of apartment buildings in $2010^{2}$. At the same time, in general, in Russia there is a decrease in volumes in 2017 by $1.2 \%$. Thus, it follows from the analysis that there are active rates of growth in the construction of residential real estate in the Penza Region.

2 Territorial body of the Federal State Statistics Service for the Penza Region URL: http://pnz.gks.ru/ (reference date: 20.09.2018). 
Table. 1 shows that the average prices in the residential property market in 2018 per sq. m. compared to 2010 increased by $22.5 \%$ in the primary market and $18.9 \%$ in the secondary market. At the same time, the Penza Region and the Tambov Region showed the lowest average price per sq. $\mathrm{m}$. compared to neighboring regions.

Table 1. Average price of the total area of housing, RUB

\begin{tabular}{|l|c|c|}
\hline \multirow{2}{*}{ Region } & \multicolumn{2}{|c|}{ Average price per sq. m. of the total area, 1Q } \\
\cline { 2 - 3 } & Primary housing market & Secondary housing market \\
\hline Penza Region & 38332 & 39226 \\
\hline Ulyanovsk Region & 38379 & 42105 \\
\hline Saratov Region & 37153 & 36040 \\
\hline Tambov Region & 31727 & 36082 \\
\hline
\end{tabular}

Despite the fact that there is no unemployment in the region and the Russian Federation, the purchasing power remains low due to the level of salary. For example, for six months of 2018, the average salary in the Penza Region, in general, increased by $10 \%$ and amounted to RUB 26,000. The highest average salary was recorded for research and development employees, enterprise managers (Fig. 1).

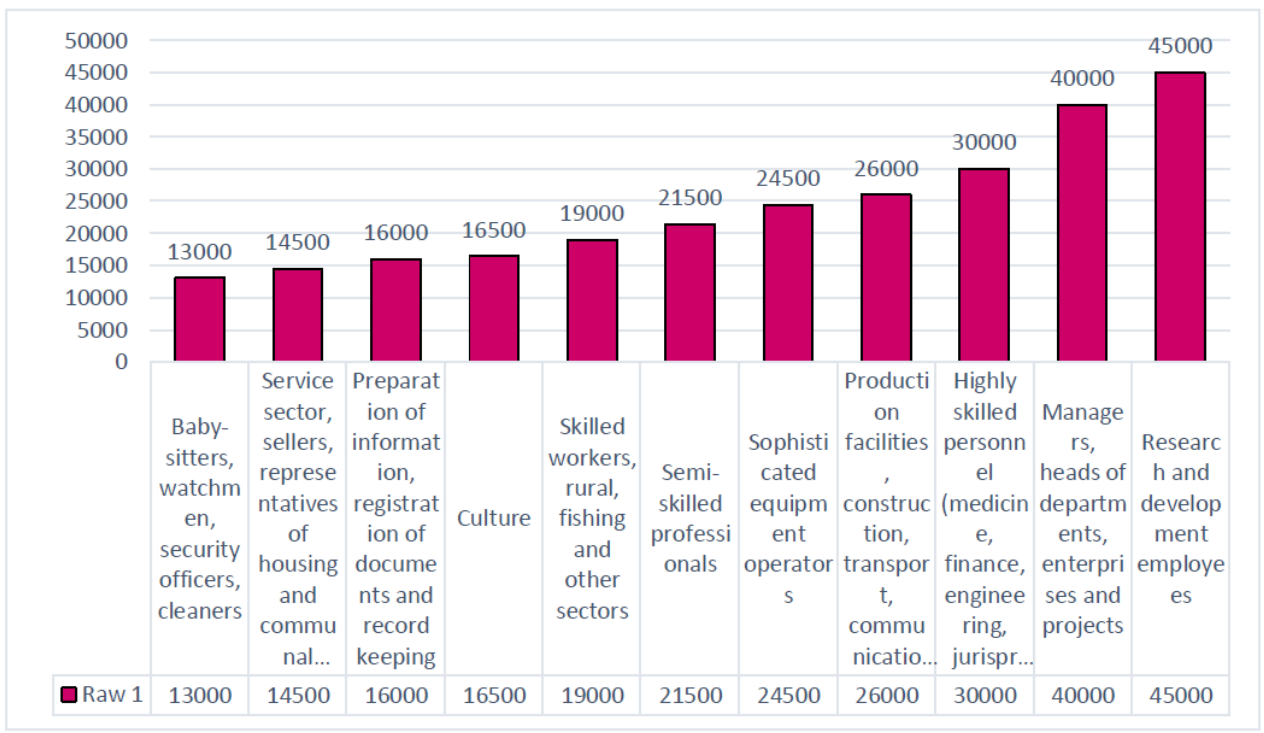

Fig. 1. Average salary of certain categories of the population of the Penza Region

There is a decrease in the population in 2018 by $0.74 \%$ compared to 2017 and by $2.2 \%$ compared to 2014, and, accordingly, the number of housing consumers. Previously, we have found that the purchasing power is higher for married couples [13]. Unfortunately, in the region there is a decrease in registered marriages. Thus, in 2017 the number of marriages was 8153 , compared to 2010 decreased by $32 \%$. The number of divorces was 5284.

The reduction in interest rates on mortgage credit lending in the Penza Region by 0.6$2 \%$ of the point led to an increase in applications by $20 \%$. Affordable Housing for Young Families state program had a big impact. However, the interest rate in Russia remains high $(7-8 \%)$, thus in Great Britain $-6.5 \%$ per annum, in France $-5 \%$, in Switzerland $-2.8 \%$ [14].

The cost of materials purchased by construction organizations also increases. This indicator increased by $10 \%$ compared to 2017. 
A positive factor in the residential real estate market of the Penza Region is the diversification of its facilities. However, not all newly built apartment buildings are provided with adequate infrastructure and transport accessibility compared to other regions [15].

At the same time, a serious problem is the deficit of housing liquidity, which leads to a decrease in the volume of sold residential real estate. Developers have to master plots of land different in their value, which affect the differences in liquidity of proposed residential real estate projects and the possibility of making a profit. The number of developers is decreasing due to amendments in the legislation (direct financing is replaced by lending). There is a process of monopolization in fixing the value per square meter.

Fig. 2 presents a mechanism model for interaction between economic agents of the residential real estate market developed based on the structural and logical method and data analysis of the state of the residential real estate market in the region.

\section{Results and discussion}

As can be seen from the above analysis, there is an active growth rate of construction of residential real estate, but it still remains unavailable to many categories of citizens.

The acquisition of a land plot in ownership or lease is the main problem for today, because banks do not go to lending projects if there is no ownership right. It also affects the cost of the property, as these costs are about $30 \%$ of the project value. In order to shorten the terms for the implementation of projects, developers need to master new construction technologies (for example, 3D printing technologies (first used in Spain), energy-saving houses, frame construction), construction materials (self-repairing concrete), renovation, increase the level of the organizational and construction process (losses from marriage and downtime are up to $12-15 \%$ of profit) [16]. Another important factor in increasing the value of the facility is that developers develop differently valuable land plots. This indicates the need to improve the system of providing developers with construction sites.

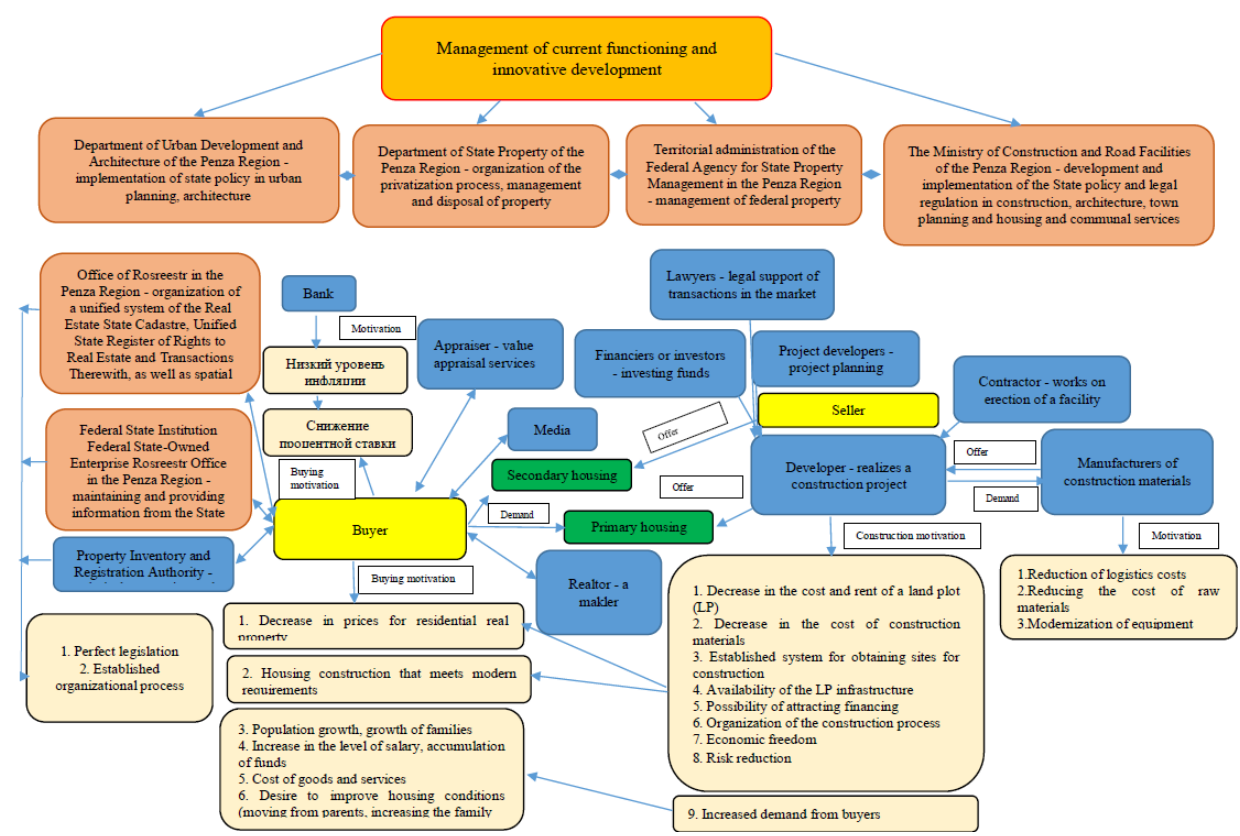

Fig. 2. Mechanism of interaction of economic agents of the residential real estate market in the context of the Penza Region 
In order to solve the problem of the provision of modern buildings with modern infrastructure, as well as the development of lands that do not enjoy investment attractiveness, local authorities need to include the construction costs of the necessary infrastructure when transferring ownership of or renting a land plot.

The price of construction materials also significantly affects the value of the residential real estate. The reasons for the inflated prices for construction materials are the costs of raw materials and logistics, as well as obsolete equipment. In this regard, in the construction industry, it is necessary to modernize the equipment, as well as use local raw materials. In the Penza Region, there are 361 deposits of minerals, 331 of which are mineral construction materials [17].

Mortgage credit lending is an important tool to improve the availability of residential real estate. It is necessary to increase the competitiveness of banking services, attract investors to the region, carry out the following programs: reduce the interest rate for residents who have a permanent residence, permanent salary, doing business.

\section{Conclusions}

Thus, at present, the Russian Federation has established the main institutions that ensure the functioning of the housing construction market in the market economy. However, the presence of negative factors in the residential real estate market hinders effective interaction of economic agents. The modern residential real estate market does not meet the needs of the modern Russian economy and does not allow increasing the availability of residential real estate for the population. In this regard, the authors propose a model of the institutional and economic mechanism for managing the regional real estate market using the structural and logical method. This model reveals the essence of the effectiveness of the institutional and economic mechanism, shows the dependence of the effectiveness of the mechanism on the behavior of the main economic agents and based on which a complex of organizational, legal and economic measures is proposed, the implementation of which in practice contributes to the development of the residential real estate market.

\section{References}

1. Zakurdaeva NS, Bakhtin AA «Karl Marx and his work Capital in modern realities» Compilation of the international scientific conference "Institutional transformation of the Russian economy in the new reality": text electronic publication. (2017) pp. 161-165 (in Rus).

2. Schachter G. Francois Quesnay: Interpreters and Critics Revisited // Am. J. Econ. Sociol (1991) no. 3, pp. 313-322.

3. Smith A. The Wealth of Nations // Science (2006) no. 4, 188 p.

4. Goldschmidt N. Walter Eucken's place in the history of ideas // Rev. Austrian Econ (2013) no. 2, pp. 127-147.

5. Izmalkov S., Sonin K., Yudkevich M. The theory of economic mechanisms // Issues of Economics (2008) no 1, pp. 4-26.

6. K. Polanyi. Economics as an institutionalized process // Economic Sociology (2001) no 2, pp.68-73

7. Bogachev U. S., Oktyabrsky A.M., Popadyuk T.G., Vasilyeva L.V. «Institutional mechanisms for supporting innovative economy in Russia» // Bulletin of the Financial University (2016) no 1, pp. 24-32 (in Rus). 
8. Istomin S.V. «Comparative Analysis of Institutional and Economic Mechanisms in the Transformed Economy» // Bulletin of the Chelyabinsk State University (2010) no 27, pp. 47-51 (in Rus).

9. North D. Institutions, institutional changes and the functioning of the economy// Beginning, (1997) $190 \mathrm{p}$.

10. A.U. Veretennikova, G.K. Omonov «The concept of an institutional mechanism in economic theory» // Journal of Economic Theory (2017) no 2, pp. 7. (in Rus)

11. Lebedeva N.N., Averina I.S. «Institutional mechanism of stimulating innovation activity of economic entities: problems and ways of their solution"// Innovations of the region, 2013, no 36, pp. 38-44. (in Russ)

12. Maksimov S.N. "Real estate as an economic asset and subject of scientific life" Economics of Real Estate "//Economics and property management (2010)no 2, pp. 57-60. (in Rus)

13. Ishamyatova I.H. «Segmentation of consumers of residential real estate as the main participants of the marketing macro environment»// Russian Journal of Management (2018) 1, pp. 13-14. (in Rus)

14. Kookueva V.V., Tsertseil U.S. "Review of foreign approaches to identifying factors in the development of the real estate market» // The Eurasian Scientific Journal (2018) no 2, 10 p. (in Russ)

15. Ishmatova I. I., Chursin A. I., Ulitskaya N. U. «Urban planning analysis and zoning of the city of Penza»//Priorytetowe obszary badawcze: od teorii do praktyki (30.05.2016 31.05.2016), 2016. - $\quad$ pp. 41-43; URL: http://xne1aajfpcds8ay4h.com.ua/files/file/scientific_conference_53/53-1.pdf

16. Isakova M.M. «Accounting and analysis of losses from marriage in construction»// Problems of modern economy (Novosibirsk) (2014) no 21, pp. 97-102. (in Rus)

17. Management of natural resources and environmental protection of the Penza region [Electronic resource] Access mode:http://www.priroda- pnz.ru. 